\title{
Case-control association analysis of Dopamine receptor polymorphisms in alcohol dependence: a pilot study in Indian males
}

Pushplata Prasad ${ }^{1,2}$, Atul Ambekar ${ }^{1}$ and Meera Vaswani ${ }^{{ }^{*}}$

\begin{abstract}
Background: Brain imaging studies and knock-out animal models have derived substantial abetment for dopamine receptor (DR) subtypes as potential candidates in susceptibility to addictive disorders, including alcohol dependence (AD). Various association studies that compared the frequencies of alleles of the dopamine D1, D2, D3 and D4 receptor genes between alcohol dependent and control subjects have produced suggestive results, though some of them are discordant in nature. In the absence of genetic data from Indian population, we evaluated genetic association of three polymorphisms namely rs4532 in DRD1, rs6280 in DRD3 and 120 bp duplication in $1.2 \mathrm{~kb}$ upstream region of DRD4 with AD.

Methods: A total of 90 cases (alcohol dependent males) and 122 age and ethnicity matched healthy male controls were recruited in the study by following DSM-IV criteria. Three polymorphisms, namely rs4532 in DRD1, rs6280 in DRD3 and $120 \mathrm{bp}$ duplication in $1.2 \mathrm{~kb}$ upstream region of DRD4 were selected (based on minor allele frequency and available literature) for genotyping by PCR-RFLP/LP method. Allele and genotype frequencies of these genetic markers were compared using Pearson's $X^{2}$ test followed by risk assessment using odds ratio. Statistical analysis of clinical parameters such as AUDIT scores of case subjects was also performed.

Results: Statistically significant associations of polymorphisms in DRD1 and DRD4 with alcoholism were found. Conclusions: Our results underscore that genetic variations in dopamine receptors D1 and D4 may influence genetic predisposition to alcoholism. Unavailability of comparative data from Indian population and small sample size necessitate replication of results in an independent cohort.
\end{abstract}

Keywords: Alcohol dependence, Dopamine receptors, Polymorphisms, Case-control study, Genetic association

\section{Background}

Alcohol dependence is a chronically relapsing addictive disorder which is characterized by compulsive and continued intake of substance of abuse despite negative consequences [1]. A key factor in development of addiction is the reinforcing capacity of drug of abuse that brings about complex changes in brain leading to neuronal adaptations [2]. Alcohol influences reward pathway through mesolimbic dopamine system in the brain. Empirical evidences from animal studies suggest that alcohol enhances the firing rates of dopaminergic neurons in the ventral tegmental area

\footnotetext{
*Correspondence: meeravaswani@yahoo.com

${ }^{1}$ National Drug Dependence Treatment Centre, All India Institute of Medical Sciences, New Delhi 110029, India

Full list of author information is available at the end of the article
}

(VTA). This is followed by increased release of dopamine in the nucleus accumbens (NAc) which forms the basis of compulsive-reinforcing properties of alcohol and the reward mechanism [3-7]. Varying densities of both the dopamine receptors and transporters in humans have been found to be associated with $\mathrm{AD}[8,9]$.

Multiple small genes and their interaction with environment cumulatively influence development of alcohol dependence [10-12]. Family, adoption and twin studies suggest that approximately $50-60 \%$ risk to AD could be attributed to genetic components [13]. Of the various pathways and genes, genetic polymorphisms in dopamine receptor (DR) subtypes are believed to influence the development and/or severity of alcoholism. Genetic association of dopamine D2 receptor (DRD2) gene with
C Biomed Central

(c) 2013 Prasad et al.; licensee BioMed Central Ltd. This is an open access article distributed under the terms of the Creative Commons Attribution License (http://creativecommons.org/licenses/by/2.0), which permits unrestricted use, distribution, and reproduction in any medium, provided the original work is properly cited. 
alcohol dependence is most widely studied $[14,15]$. We have previously reported significant association of -141C Ins/Del polymorphism in DRD2 with AD in a northIndian cohort [16]. In the present study we have investigated the association of DRD1, DRD3 \& DRD4 gene polymorphisms with $\mathrm{AD}$ in a population of north-Indian origin.

Dopamine receptor -1 (DRD1) is considered a candidate gene in alcohol dependence, particularly with regard to its role in the prefrontal cortex in modulation of cognitive processes [17]. A recent study reported that miR-382 which directly targets DRD1 in the NAc plays a crucial role in mediating the behavioral responses to alcohol [18]. Among the different polymorphisms of the DRD1 gene, none have been associated with alcohol dependence. However, rs4532 SNP, a -48AG Dde I polymorphism in the 5'-UTR of the gene, displayed a modest role in a large set of phenotypes including addictive behaviors [19].

Dopamine receptor D3 (DRD3) is highly expressed in the limbic area [20] in the NAc and influences the reward process of addiction behavior. DRD3 is not involved in the direct reinforcing effects of drugs of abuse, but seems to contribute to the motivational aspects and/ or the effects of cues over behaviors [21]. In addition, depleted D2/D3 receptors levels in human striatum found by brain imaging studies have become an evident marker of addiction in patients, even during periods of withdrawal [22]. However, genetic association studies carried out in different populations report conflicting results on influence of genetic polymorphisms of DRD3 on $\mathrm{AD}$ [23-27].

Only a few genetic association studies have been conducted with DRD4 and DRD5. These receptors are expressed in cortex and hippocampus and may modulate some response to drugs. Recent findings suggest that DRD4 may be involved in cue reactivity [28].

Incidence of alcohol dependence (AD) is increasing with the changing lifestyle. A lifetime prevalence of $6.5 \%$ in India has been estimated [29]. Thus, studying the bio-genetic factors for $\mathrm{AD}$ in Indian population becomes imperative.

\section{Methods}

\section{Study population}

Details of the study population have been published elsewhere [16]. Briefly, ethical committee clearance from the All India Institute of Medical Sciences (AIIMS, New Delhi) and written informed consent from the study participants were obtained prior to sample collection. Using the DSM-IV criteria [30], clinical assessments were carried out by a qualified Psychiatrist. One hundred and forty male alcohol dependent subjects attending the outpatient department (OPD) at National Drug Dependence
Treatment Centre, AIIMS, were screened. Out of these, 37 were polysubstance users and 13 had co-morbid depression/anxiety/or schizophrenia, and therefore, were excluded from the study. Remaining 90 unrelated outpatients with alcohol dependence, in the age range of 1860 years, were enrolled as cases. A total of 122 unrelated healthy male employees of the hospital, without any history of substance use (except nicotine) were included as controls in the study. Since nicotine use is widely prevalent among males in India, neither case nor controls were excluded on the basis of their nicotine use. Subjects with a current diagnosis of dependence or abuse of other substances except nicotine, a current psychiatric diagnosis, and evidence of severe neurologic or psychiatric disorders, mental retardation were excluded from the study.

All patients were assessed for alcohol use parameters using the Alcohol Use Disorders Identification Test (AUDIT) [31] and a semi-structured questionnaire. The semi-structured questionnaire included items on clinical details like ethnicity, family history, age at first use of alcohol, quantity of alcohol consumption (g/day), duration of alcohol use, duration of alcohol dependence, age at onset of dependence, presence/absence of delirium and any other psychiatric or physical illness. The same semistructured questionnaire was used for assessment of the control population as well. The laboratory assessments included liver function tests (LFT) such as serum proteins, albumin, bilirubin, glutamic oxaloacetic transaminase (SGOT), glutamic pyruvic transaminase (SGPT), and gamma-glutamyltransferase (GGT), were estimated on autoanalyser using biochemical kits from Boehringer Mannheim kits (Germany). The study was conducted in accordance with worldwide good clinical practice (GCP) standards and confirmed to acceptable ethical standards as outlined by local requirements and the Declaration of Helsinki (World Medical Association, 1989).

\section{Genetic analysis}

Phenol chloroform organic extraction method [32] was employed for DNA isolation from peripheral blood lymphocytes. Three polymorphisms namely rs 4532 in $D R D 1$, rs6280 in DRD3 and 120 bp duplication in $1.2 \mathrm{~kb}$ upstream region of $D R D 4$ were selected based on prior published genetic association reports, information content, minor allele frequency (MAF) and validation evidence. SNP genotyping was done following polymerase chain reaction (PCR)-restriction fragment length polymorphisms (RFLP)/length polymorphism (LP) approach reported previously [33].

\section{Statistical analysis}

Clinical variables were compared between alcohol dependent and control subjects using $X^{2}$ test for nominal variables 
Table 1 Demographic and clinical parameters significantly different between the case and control groups (presented as Mean; SD/SE)

\begin{tabular}{lccc}
\hline Characteristics & Case & Controls & OR (95\% Cl) \\
\hline Audit Score & $32.12 \pm 5.59$ & $1.043 \pm 1.58$ & $31.07(29.85-32.29)$ \\
$\begin{array}{l}\text { Alcohol intake } \\
\text { (g/day) }\end{array}$ & $183.89 \pm 104.54$ & $2 \pm 0.5$ & $79.35(78.91-79.78)$ \\
$\begin{array}{l}\text { Total bilirubin } \\
\text { (mg/dl) }\end{array}$ & $1.96 \pm 0.78$ & $0.7 \pm 0.2$ & $1.26(1.05-1.46)$ \\
SGOT (U/l) & $84.21 \pm 27.76$ & $27.02 \pm 09.71$ & $57.19(50.95-63.42)$ \\
SGPT $(\mathrm{U} / \mathrm{l})$ & $83.13 \pm 26.29$ & $28.30 \pm 11.49$ & $55.11(48.95-61.27)$ \\
GGT $(\mathrm{U} / \mathrm{l})$ & $210.02 \pm 42.02$ & $24.95 \pm 11.88$ & $185.07(175.88-194.26)$ \\
TG $(\mathrm{mg} / \mathrm{dl})$ & $198.58 \pm 108.01$ & $121.59 \pm 11.8$ & $76.99(54.47-99.50)$ \\
\hline
\end{tabular}

and student's $t$-test/Mann Whitney's $U$ test for continuous variables.

Hardy-Weinberg equilibrium (HWE) was calculated for the genetic polymorphisms by $\chi^{2}$ test. Allelic and genotypic associations of SNPs were evaluated by Pearson's $\chi^{2}$ test followed by risk assessment using odds ratio and $95 \%$ confidence of interval (CI) computation. Power of the sample size for each of the SNPs was calculated using PAWE software version $1.2[34,35]$.

\section{Results}

\section{Clinical analysis}

Demographic and Clinical characteristics of the study population are reported previously [29]. On almost all demographic parameters, the control group was largely similar to the case group. However, larger proportion of $\mathrm{AD}$ subjects had education only up to primary school (i.e. five years of formal schooling). The values for various clinical parameters such as audit score, alcohol intake (g/day) SGOT, SGPT, GGT, cholesterol, and triglycerides $(\mathrm{TG})]$ were significantly higher $(\mathrm{P}<0.01)$ among alcohol dependent cases as compared to the control group [Table 1].

\section{Genetic analysis}

Genotypic and allelic frequencies of two SNPs in DRD1 and DRD3 were in agreement with the Hardy-Weinberg equilibrium (HWE). However, ins/del polymorphism in DRD4 deviated from HWE. Allele and genotype frequencies of SNPs in DRD1,DRD3, and DRD4 and their association status with $\mathrm{AD}$ along with power of sample set are presented in Table 2. A significant allelic and genotypic associations of $-48 \mathrm{~A}>\mathrm{G}$ SNP of DRD1 and -120 Ins/Del polymorphism of $D R D 4$ were observed with alcohol dependence. No association between Ser9Gly SNP of DRD3 and alcoholism was observed.

\section{Discussion}

Alcohol dependence is a heterogeneous disorder associated with a spectrum of psychiatric and medical problems. A complex interaction of genetic and environmental factors underlies the biogenesis of AD. Dopamine being an important neurotransmitter in the reward pathway, the associated genes and their polymorphisms are of significant interest. Genes encoding dopamine receptor (DR) subtypes have received considerable attention as a potential candidate that may affect susceptibility to alcoholism [36]. There is strong support for the dopamine hypothesis of the reinforcing effects of ethanol and development of alcohol dependence [2]. We tested genetic association of three polymorphisms in the dopaminergic pathway genes namely rs4532 in $D R D 1$, rs6280 in $D R D 3$ and a 120 bp duplication in $1.2 \mathrm{~kb}$ upstream region of $D R D 4$ with alcohol dependence among male subjects from the North India.

rs4532 present in $5^{\prime}$ UTR of DRD1 is a widely investigated polymorphism for genetic association with mental health and addiction. This SNP has shown significant association with alcohol dependence and associated disorders like bipolar disorder $[37,38]$ and novelty seeking, persistence and harm avoidance $[39,40]$. In line with such genetic associations, rs4532 showed significant association with alcohol dependence in the present study.

Table 2 Allele and genotype frequencies of polymorphisms in DRD1, 3, 4 and their association status with alcohol dependence

\begin{tabular}{|c|c|c|c|c|c|c|c|c|c|}
\hline SNPs & & Genotype & & $x^{2}(\mathrm{P})$ & & & $x^{2}(\mathrm{P})$ & OR $(95 \% \mathrm{Cl})$ & Power (G\%) \\
\hline D1 $-48 A>G$ & $A A$ & AG & GG & & A & G & & & \\
\hline Cases & 0.14 & 0.49 & 0.37 & $7.65(0.02)$ & 0.38 & 0.62 & $3.96(0.04)$ & $1.77(1.01-3.10)$ & $76 \%$ \\
\hline Controls & 0.29 & 0.46 & 0.25 & & 0.52 & 0.48 & & & \\
\hline D3 Ser9Gly & $\mathrm{CC}$ & CT & TT & & C & $T$ & & & \\
\hline Cases & 0.29 & 0.62 & 0.09 & $5.48(0.07)$ & 0.60 & 0.40 & $0.51(0.47)$ & $1.22(0.7-2.15)$ & $5 \%$ \\
\hline Controls & 0.30 & 0.50 & 0.20 & & 0.55 & 0.45 & & & \\
\hline D4 120 Ins/Del & Ins/Ins & Ins/Del & Del/Del & & Ins & Del & & & \\
\hline Cases & 0.45 & 0.49 & 0.06 & $11.4(0.00)$ & 0.72 & 0.28 & $6.14(0.01)$ & $2.10(1.17-3.79)$ & $86 \%$ \\
\hline Controls & 0.39 & 0.31 & 0.30 & & 0.55 & 0.45 & & & \\
\hline
\end{tabular}


Significant power of association further indicates that 48A > G SNP could be a predisposing factor in North Indian subjects. Further, this regulatory SNP has been reported to be significantly associated with severity of alcohol-related problems, as measured by the AUDIT score in a gene dose-dependent manner [40], high MAST score [19], and elevated sensation seeking scores [39]. In concurrence to above, significantly higher audit score, higher alcohol consumption, followed by impairment of liver function tests were seen in case subjects with G allele or GG genotype. Such observations may support the hypothesis of Batel et al. [9] that DRD1 could play an indirect role in alcohol dependence through severity rather than presence or absence of alcohol dependence.

DRD3 gene is located in the limbic area, in particular in the nucleus accumbens, which plays a significant role in the reward process of addiction behavior [27]. The BalI polymorphism (rs6280; Ser9Gly) in DRD3 is a point mutation that results in substitution of a glycine for serine residue in the extracellular receptor N-terminal domain [41]. Genetic analyses across different populations report inconsistent association of this non-synonymous SNP with alcoholism. Positive associations $[27,42]$ supported involvement of DRD3 in the development of addiction to alcohol. However, large number of studies in French, Korean and Caucasian populations reported no association of rs6280 [23,36,43] with AD, suggesting that the SNP may not be important in the genesis of alcoholism. The present study did not record any association of rs6280 with AD. This is in complete agreement with negative findings in different populations as indicated above.

The $D R D 4$ polymorphism 120 bp tandem duplication, located $1.2 \mathrm{~kb}$ upstream of the initiation codon has been well studied in context of attention deficit hyperactivity disorder (ADHD). This repeat sequence has been hypothesized to have a potential role in transcription regulation. McCracken et al. (2000) reported significant association with ADHD and indicated that duplication could be a risk factor by decreasing the expression of the DRD4 gene [44]. Further, transcription regulation was suggested to be mediated by the presence of consensusbinding sequences for several transcription factors in this region [45]. However, the genetic association studies involving the DRD4 polymorphism and ADHD have been dissonant [46-48]. Association of DRD4 with alcohol dependence has not been largely investigated. A study by Rogers et al. (2004) reported an association with novelty seeking in bipolar and alcoholic families [49]. We therefore, genotyped this polymorphism in Indian population and found a significant association with -120Ins (duplication) allele conferring approximately two times higher risk to alcohol dependence as compared to the control population. Susceptibility conferred by the duplication allele may draw support from the genetic association study of this polymorphism with ADHD where the duplication allele is reported to confer risk by negatively regulating $D R D 4$ transcription [44]. However, the -120 Ins/Del polymorphism in DRD4 deviated from HWE in this study and therefore, the association result obtained for this marker must be interpreted with caution.

\section{Conclusions}

Exploration of the underlying genetic factors in alcohol dependence in humans as well as in animal models has made great strides over the past four decades, and newer and finer approaches are being continuously evaluated. The present post-hoc genetic analysis of three dopamine receptor genes in $\mathrm{AD}$ indicates that the polymorphisms in the DRD1 and DRD4 may influence susceptibility to $\mathrm{AD}$ in the subjects of north Indian origin.

\section{Competing interests}

The authors declare that they have no competing interests.

\section{Authors' contributions}

All authors have read and approved the final manuscript. PP was involved in conceptualization of the project, study design, carried out molecular genetics and statistical analyses, compiled the data, wrote the manuscript. AA was the clinical investigator involved in study design, defining exclusion and inclusion criteria of study subjects and was mainly responsible for identification of study subjects; MV was the principal scientist and coordinator of the project, involved in study design, critical inputs and finalization of the manuscript.

\section{Author details}

${ }^{1}$ National Drug Dependence Treatment Centre, All India Institute of Medical Sciences, New Delhi 110029, India. ${ }^{2}$ Present Address: TERI-Deakin Nanobiotechnology Centre, Biotechnology and Management of Bio-resources Division, The Energy and Resources Institute, India Habitat Centre, Lodhi Road, New Delhi 110003, India.

Received: 5 March 2013 Accepted: 11 October 2013

Published: 17 October 2013

\section{References}

1. Deroche-Gamonet V, Belin D, Piazza PV: Evidence for addiction-like behavior in the rat. Science 2004, 305(5686):1014-1017.

2. Pierce RC, Kumaresan V: The mesolimbic dopamine system: the final common pathway for the reinforcing effect of drugs of abuse? Neurosci Biobehav Rev 2006, 30(2):215-238.

3. Weiss F, Lorang MT, Bloom FE, Koob GF: Oral alcohol selfadministration stimulates dopamine release in the rat nucleus accumbens: genetic and motivational determinants. J Pharmacol Exp Ther 1993, 267:250-258.

4. Gatto GJ, McBride WJ, Murphy JM, Lumeng L, Li TK: Ethanol self-infusion into the ventral tegmental area by alcohol preferring rats. Alcohol 1994, 11:557-564.

5. Nurmi M, Sinclair JD, Kiianmaa K: Dopamine release during ethanol drinking in AA rats. Alcohol Clin Exp Res 1998, 22(8):1628-1633.

6. Gonzales RA, Weiss F: Suppression of ethanol-reinforced behavior by naltrexone is associated with attenuation of the ethanol-induced increase in dialysate dopamine levels in the nucleus accumbens. J Neurosci 1998, 18(24):10663-10671.

7. Rodd ZA, Melendez RI, Bell RL, Kuc KA, Zhang Y, Murphy JM, McBride WJ: Intracranial self-administration of ethanol within the ventral tegmental area of male Wistar rats: evidence for involvement of dopamine neurons. J Neurosci 2004, 24(5):1050-1057. 
8. Martinez D, Gil R, Slifstein M, Hwang DR, Huang Y, Perez A, Kegeles L, Talbot P, Evans S, Krystal J, Laruelle M, Abi-Dargham A: Alcohol dependence is associated with blunted dopamine transmission in the ventral striatum. Biol Psychiatry 2005, 58(10):779-786.

9. Batel P, Houchi H, Daoust M, Ramoz N, Naassila M, Gorwood P: A haplotype of the DRD1 gene is associated with alcohol dependence. Alcohol Clin Exp Res 2008, 32(4):567-572.

10. Edenberg $H J$, Foround $T$ : The genetics of alcoholism: identifying specific genes through family studies. Addict Biol 2006, 11:386-396.

11. Buscemi $L$, Turchi $C$ : An overview of the genetic susceptibility to alcoholism. Med Sci Law 2011, 51(Suppl 1):S2-S6.

12. Morozova TV, Goldman D, Mackay TF, Anholt RR: The genetic basis of alcoholism: multiple phenotypes, many genes, complex networks. Genome Biol 2012, 13(2):239.

13. McGue M: The behavioral genetics of alcoholism. Current Directions in Psychological Science 1999, 8:109-115.

14. Gelernter J, Kranzler H: D2 dopamine receptor gene (DRD2) allele and haplotype frequencies in alcohol dependent and control subjects: no association with phenotype or severity of phenotype. Neuropsychopharmacology 1999, 20(6):640-649

15. Ponce G, Jimenez-Arriero MA, Rubio G, Hoenicka J, Ampuero I, Ramos JA, Palomo T: The A1 allele of the DRD2 gene (Taql A polymorphisms) is associated with antisocial personality in a sample of alcohol-dependent patients. Eur Psychiatry 2003, 18(7):356-360.

16. Prasad P, Ambekar A, Vaswani M: Dopamine D2 receptor polymorphisms and susceptibility to alcohol dependence in Indian males: a preliminary study. BMC Med Genet 2010, 11:24.

17. Rinaldi A, Mandillo S, Oliverio A, Mele A: D1 and D2 receptor antagonist injections in the prefrontal cortex selectively impair spatial learning in mice. Neuropsychopharmacology 2007, 32(2):309-319.

18. Li J, Li J, Liu X, Qin S, Guan Y, Liu Y, Cheng Y, Chen X, Li W, Wang S, Xiong $\mathrm{M}$, Kuzhikandathil EV, Ye $\mathrm{JH}$, Zhang C: MicroRNA expression profile and functional analysis reveal that miR-382 is a critical novel gene of alcohol addiction. Mol Med: EMBO; 2013.

19. Comings DE, Gade R, Wu S, Chiu C, Dietz G, Muhleman D, Saucier G, Ferry L, Rosenthal RJ, Lesieur HR, Rugle LJ, MacMurray P: Studies of the potential role of the dopamine D1 receptor gene in addictive behaviors. Mol Psychiatry 1997, 2(1):44-56.

20. Gurevich EV, Joyce JN: Distribution of dopamine D3 receptor expressing neurons in the human forebrain: comparison with D2 receptor expressing neurons. Neuropsychopharmacology 1999, 20(1):60-80

21. Le Foll B, Gallo A, Le Strat Y, Lu L, Gorwood P: Genetics of dopamine receptors and drug addiction: a comprehensive review. Behav Pharmacol 2009, 20(1):1-17.

22. Volkow ND, Fowler JS, Wang GJ, Baler R, Telang F: Imaging dopamine's role in drug abuse and addiction. Neuropharmacology 2009, 56(1):3-8.

23. Gorwood P, Martres MP, Adès J, Sokoloff P, Noble EP, Geijer T, Blum K, Neiman J, Jönsson E, Feingold J, et al: Lack of association between alcohol-dependence and D3 dopamine receptor gene in three independent samples. Am J Med Genet 1995, 60(6):529-531.

24. Parsian A, Chakraverty S, Fisher $L$, Cloninger CR: No association between polymorphisms in the human dopamine D3 and D4 receptors genes and alcoholism. Am J Med Genet 1997, 74(3):281-285.

25. Agrawal A, Wetherill L, Bucholz KK, Kramer J, Kuperman S, Lynskey MT, Nurnberger JI Jr, Schuckit M, Tischfield JA, Edenberg HJ, Foroud T, Bierut LJ: Genetic influences on craving for alcohol. Addict Behav 2013, 38(2):1501-1508.

26. Duaux E, Gorwood P, Griffon N, Bourdel MC, Sautel F, Sokoloff P, Schwartz JC, Ades J, Lôo H, Poirier MF: Homozygosity at the dopamine D3 receptor gene is associated with opiate dependence. Mol Psychiatry 1998, 3(4):333-336.

27. Limosin F, Romo L, Batel P, Adès J, Boni C, Gorwood P: Association between dopamine receptor D3 gene Ball polymorphism and cognitive impulsiveness in alcohol-dependent men. Eur Psychiatry 2005, 20(3):304-306.

28. McGeary J: The DRD4 exon 3 VNTR polymorphism and addiction-related phenotypes:a review. Pharmacol Biochem Behav 2009, 93(3):222-229.

29. Ray R: The Extent Pattern and Trends of drug abuse in India: National Survey Ministry of Social Justice and Empowerment, Government of India and United Nations Office on Drugs and Crime. India: New Delhi; 2004

30. American Psychiatric Association: Diagnostic and statistical manual of mental disorders. 4. Washington, DC: American Psychiatric Press; 1994
31. Saunders JB, Aasland OG, Babor TF, de la Fuente JR, Grant M: Development of the Alcohol Use Disorders Identification Test (AUDIT): WHO Collaborative Project on Early Detection of Persons with Harmful Alcohol Consumption-II. Addiction 1993, 88:791-804.

32. Miller SA, Dykes DD, Polesky HF: A simple salting out procedure for extracting DNA from human nucleated cells. Nucleic Acids Res 1988, 16:1215.

33. Prasad P, Kumar KM, Ammini AC, Gupta A, Gupta R, Thelma BK: Association of dopaminergic pathway gene polymorphisms with chronic renal insufficiency among Asian Indians with type-2 diabetes. BMC Genet 2008, 9:26.

34. Gordon D, Finch SJ, Nothnagel M, Ott J: Power and sample size calculations for case-control genetic association tests when errors present: application to single nucleotide polymorphisms. Hum Hered 2002, 54:22-33.

35. Gordon D, Levenstien MA, Finch SJ, Ott J: Errors and linkage disequilibrium interact multiplicatively when computing sample sizes for genetic casecontrol association studies. Pac Symp Biocomput 2003:490-501.

36. Lee MS, Ryu SH: No association between the dopamine D3 receptor gene and Korean alcohol dependence. Psychiatr Genet 2002, 12(3):173-176.

37. Severino G, Congiu D, Serreli C, De Lisa R, Chillotti C, Del Zompo M, Piccardi MP: A48G polymorphism in the D1 receptor genes associated with bipolar I disorder. Am J Med Genet B Neuropsychiatr Genet 2005, 134B(1):37-38.

38. Dmitrzak-Weglarz M, Rybakowski JK, Slopien A, Czerski PM, LeszczynskaRodziewicz A, Kapelski P, Kaczmarkiewicz-Fass M, Hauser J: Dopamine receptor D1 gene -48A/G polymorphism is associated with bipolar illness but not with schizophrenia in a Polish population. Neuropsychobiology 2006, 53(1):46-50.

39. Limosin F, Loze JY, Rouillon F, Adès J, Gorwood P: Association between dopamine receptor D1 gene Ddel polymorphism and sensation seeking in alcohol-dependent men. Alcohol Clin Exp Res 2003, 27(8):1226-1228.

40. Kim DJ, Park BL, Yoon S, Lee HK, Joe KH, Cheon YH, Gwon DH, Cho SN, Lee HW, NamGung S, Shin HD: 5' UTR polymorphism of dopamine receptor D1 (DRD1) associated with severity and temperament of alcoholism. Biochem Biophys Res Commun 2007, 357(4):1135-1141.

41. Rietschel M, Nöthen MM, Lannfelt L, Sokoloff P, Schwartz JC, Lanczik M, Fritze J, Cichon S, Fimmers R, Körner J, Moller HJ, Propping P: A serine to glycine substitution at position 9 in the extracellular $\mathrm{N}$-terminal part of the dopamine D3 receptor protein: no role in the genetic predisposition to bipolar affective disorder. Psychiatry Res 1993, 46(3):253-259.

42. Sander T, Harms H, Podschus J, Finckh U, Nickel B, Rolfs A, Rommelspacher H, Schmidt LG: Dopamine D1, D2 and D3 receptor genes in alcohol dependence. Psychiatr Genet 1995, 5(4):171-176.

43. Wiesbeck GA, Dürsteler-MacFarland KM, Wurst FM, Walter M, Petitjean S, Müller S, Wodarz N, Böning J: No association of dopamine receptor sensitivity in vivo with genetic predisposition for alcoholism and DRD2/ DRD3 gene polymorphisms in alcohol dependence. Addict Biol 2006, 11(1):72-75

44. McCracken JT, Smalley SL, MCGough JJ, Crawford L, Del'Homme M, Cantor RM, Liu A, Nelson SF: Evidence for linkage of a tandem duplication polymorphism upstream of the dopamine D4 receptor gene (DRD4) with attention deficit hyperactivity disorder (ADHD). Mol Psychiatry 2000, 5:531-536.

45. Szantai E, Szmola R, Sasvari-Szekely M, Guttman A, Ronai Z: The polymorphic nature of the human dopamine D4 receptor gene: a comparative analysis of known variants and a novel 27 bp deletion in the promoter region. BMC Genet 2005, 6:39.

46. Kereszturi E, Kiraly O, Csapo Z, Tarnok Z, Gadoros J, Sasvari-Szekely M, Nemoda Z: Association between the 120-bp duplication of the dopamine D4 receptor gene and attention deficit hyperactivity disorder: genetic and molecular analyses. Am J Med Genet B Neuropsychiatr Genet 2007, 144B(2):231-236

47. Bhaduri N, Das M, Sinha S, Chattopadhyay A, Gangopadhyay PK, Chaudhuri K, Singh M, Mukhopadhyay K: Association of dopamine D4 receptor (DRD4) polymorphisms with attention deficit hyperactivity disorder in Indian population. Am J Med Genet B Neuropsychiatr Genet 2006, 141B(1):61-66. 
48. Brookes $K J, X u X$, Chen CK, Huang YS, Wu YY, Asherson P: No evidence for the association of DRD4 with ADHD in a Taiwanese population withinfamily study. BMC Med Genet 2005, 6:31.

49. Rogers $G$, Joyce P, Mulder R, Sellman D, Miller A, Allington M, Olds R, Wells E, Kennedy M: Association of a duplicated repeat polymorphism in the 5 -untranslated region of the DRD4 gene with novelty seeking. Am J Med Genet B Neuropsychiatr Genet 2004, 126B(1):95-98.

doi:10.1186/1756-0500-6-418

Cite this article as: Prasad et al: Case-control association analysis of

Dopamine receptor polymorphisms in alcohol dependence: a pilot study in Indian males. BMC Research Notes 2013 6:418.

\section{Submit your next manuscript to BioMed Central and take full advantage of:}

- Convenient online submission

- Thorough peer review

- No space constraints or color figure charges

- Immediate publication on acceptance

- Inclusion in PubMed, CAS, Scopus and Google Scholar

- Research which is freely available for redistribution 